\title{
PENGARUH PERCERAIAN ORANGTUA BAGI PSIKOLOGIS ANAK
}

\author{
Uswatun Hasanah \\ IAIN Metro Lampung \\ uswahdeini@gmail.com
}

\begin{abstract}
Abstrak
The purpose of this paper is to know the effect of parental divorce on children's psychological. The method used qualitative research with a case study approach. The subject in this study amounted to one pair by using a purposive sampling technique that is sampling where the researcher has determined the criteria for the research subjects. The results of this study indicate that divorced parents will have a psychological effect on the child including the child receiving less attention, protection, and love from his father and mother.
\end{abstract}

Keywords: Divorce, Parents, Children

\section{PENDAHULUAN}

Anak adalah korban yang paling terluka ketika ayah ibunya memutuskan untuk bercerai. Anak merasakan ketakutan, ketika orangtua bercerai, anak takut tidak akan mendapatkan kasih sayang ayah ibunya yang tidak tinggal satu rumah. Prestasi di sekolahnya akan menurun, dan anak lebih senang menyendiri (Haryanie, dkk, 2013). Kondisi rumah tangga yang broken sering anak-anak mengalami depresi mental (tekanan mental), sehingga tidak jarang anak-anak yang hidup dalam keluarganya yang demikian cenderung akan berperilaku sosialnya jelek. Jadi salah satu penyebab anak-anak yang bermasalah di sekolah adalah karena faktor broken home keluarga mereka (Azis, 2019).

Pada umumnya keluarga terdiri atas ayah, ibu, dan anak-anak. Ayah dan ibu berperan sebagai orangtua bagi anakanaknya. Namun, dalam kehidupan nyata sering dijumpai keluarga dimana salah satu orang tuanya tidak ada. Keadaan ini disebut keluarga dengan orang tua tunggal. Orang tua tunggal merupakan orang tua yang secara sendirian membesarkan anakanaknya tanpa kehadiran, dukungan, dan tanggung jawab pasangannya. Setiap orang tidak pernah berharap menjadi orang tua tunggal, keluarga lengkap pasti idaman setiap orang, namun adakalanya nasib berkehendak lain. Pada kenyataannya, kondisi ideal tersebut tidak selamanya dapat dipertahankan atau diwujudkan. Banyak dari orang tua yang karena kondisi tertentu mengasuh, membesarkan dan mendidik anaknya sendiri. Kasus orang tua tunggal karena perceraian maupun kematian pasangan sangat banyak terjadi diseluruh dunia, termasuk Indonesia (Cahyani, 2016).

\section{METODE}

Dalam penelitian menggunakan metode kualitatif, yaitu prosedur penelitian yang menghasilkan data deskriptif berupa kata-kata tertulis atau lisan dari orang-orang dan perilaku yang dapat diamati. Pendekatan kualitatif yang diambil adalah kualitatif dengan jenis studi kasus yaitu suatu model penelitian kualitatif yang terperinci tentang individu atau unit sosial tertentu dalam kurun waktu tertentu. Penelitian Kualitatif dengan pendekatan studi kasus. Dalam Subjek dalam penelitian ini berjumlah 1 Pasangan dengan menggunakan teknik pengambilan sampel purposive sampling yaitu pengambilan sampel dimana peneliti telah menentukan kriteria untuk subjek penelitian. Adapun kriteria yang ditentukan oleh peneliti adalah Pasangan Suami Istri yang bercerai dan memiliki anak. 


\section{HASIL PENELITIAN DAN PEMBAHASAN}

Setelah dilakukan pengumpulan data menggunakan wawancara semi terstruktur dengan panduan guide interview yang sebelumnya telah disiapkan. Didapatkan hasil bahwa anak-anak mengalami kondisi dimana, mereka tidak menerima keberadaan ayahnya jika sang ayah membawa perempuan lain yang bukan ibunya sendiri. Dengan demikian, anak mengalami ketidaknyamanan di dalam berkomunikasi dengan ayahnya. Sehingganya, sang Ibu dari anak-anak tersebut, harus bisa mengatur waktu dalam berkomunikasi dengan ayahnya agar anak-anak tidak kekurangan kasih sayang dari kedua orangtuanya meskipun sudah bercerai.

\section{Definisi Keluarga}

Pendidikan adalah investasi yang terpenting dan dilakukan oleh orang tua bagi masa depan anaknya. Sejak anak lahir ke dunia, ia memiliki banyak potensi dan harapan untuk berhasil di kemudian hari. Selain itu, keluarga merupakan lingkungan pendidikan pertama dan utama bagi anak. Keluarga berfungsi sebagai (trasmiter budaya atau mediator) sosial budaya bagi anak (Isma, 2016).

Keluarga adalah dunia yang pertama bagi anak, yang memberikan sumbangan mental dan fisik terhadap hidupnya. Melalui interaksi dalam keluarga, anak tidak hanya mengenal diri dan orang tuanya melainkan juga mengenal kehidupan masyarakat dan alam sekitarnya. Orang tua sebagai pendidik sesungguhnya merupakan peletak dasar kepribadian anak. Dasar kepribadian tersebut akan berperan selama berlangsungnya kehidupan. Keluarga merupakan lingkungan yang paling bertanggung jawab mendidik anak-anaknya. Pendidikan yang diberikan orangtua seharusnya memberikan dasar bagi pendidikan, proses sosialisasi dan kehidupannya di masyarakat. Keluarga menjadi kelompok pertama (primary group) tempat meletakan dasar kepribadian di dalam keluarga. Orangtua memegang peranan membentuk sistem interaksi yang intim dan berlangsung lama ditandai oleh loyalitas pribadi, cinta kasih dan hubungan yang penuh kasih sayang. Peran orangtua adalah dengan membenahi mental higeine anak. Secara umum orang-orang memandang bahwa keluarga merupakan sumber pendidikan moral yang paling utama bagi anak-anak. Ayah dan Ibunya sebagai guru pertama mereka dalam pendidikan moral. Mereka jugalah yang memberikan pengaruh paling lama terhadap perkembangan moral anak-anak, ketika di sekolah, para guru pengajar akan berubah setiap tahunnya, tetapi di luar sekolah anakanak tentunya memiliki sedikitnya satu orangtua yang memberikan bimbingan (Hasanah, 2017).

Keluarga adalah sekumpulan orang yang hidup bersama dalam tempat tinggal bersama, dan masing-masing anggota merasakan pertautan batin sehingga terjadi saling mempengaruhi dan memperhatikan. Pada dasarnya keluarga adalah sebuah komunitas dalam satu atap, kebahagiaan dalam keluarga dapat dirasakan apabila suami, istri dan anak tinggal dan hidup bersama saling berbagi suka maupun duka. Kenyataannya masih ada keluarga yakni suami dan istri hidup terpisah yang disebabkan oleh perceraian, masing-masing mencari kehidupannya sendiri. Sedangkan anak-anak harus tinggal bersama dengan salah satu orangtuanya atau keluarganya. Tentunya pola asuh yang diterima oleh anak berbeda ketika masih tinggal dan hidup bersama dengan ayah dan ibunya. Komunikasi memegang peranan penting dalam kehidupan manusia pada umumnya, hal ini tentunya berlaku bagi anak pasca bercerainya orangtua, karena lewat komunikasi dapat terlihat bagaimana anak dengan predikat broken home menunujukkan perilakunya di lingkungan masyarakat (Mokalu, dkk, 2015).

Keluarga merupakan suatu kelompok yang terdiri dari dua orang atau lebih yang terikat oleh ikatan darah, perkawinan, serta 
tinggal bersama. Dewasa ini proses sosialisasi didalam keluarga sudah mulai terganggu dengan adanya beberapa permasalahan, mulai dari adaya masalah perceraian, kematian, ataupun penyebab lainnya yang menimbulkan dampak ketidakharmonisan hubungan suatu keluarga. Single parent merupakan salah satu penyebab ketidak harmonisan keluarga, namun tidak semua keluarga yang dibina oleh single parent tidak harmonis (Jannah, 2018).

Keluarga adalah kunci pendidikan dasar anak-anak terutama dalam mengembangkan nilai-nilai moral yang menjadi penopang bagi keutuhan pribadinya. Seringkali justru situasi keluarga dan lingkungan ikut serta menciptakan suasana yang kurang mendorong anak mengenal dan memahaminya secara mudah. Pada awal kehidupannya, seorang anak telah dibentuk oleh nilai-nilai orang dewasa. Anak-anak telah belajar banyak sejak awal, bahkan sejak sebelum dilahirkan, tanpa disadari orangtuanya sudah mengungkapkan nilai-nilai mereka dengan cara yang akan mempengaruhi oranglain (Hasanah, 2018).

Adapun fungsi dari keluarga diantaranya yaitu: fungsi pengaturan seksual, fungsi reproduksi, fungsi sosialisasi, fungsi penentuan status, dan fungsi ekonomi. Adanya fungsi-fungsi tersebut menjadikan keluarga merasakan kenyamanan dari masing-masing anggota keluarga. Keluarga merupakan lingkungan yang terdekat untuk membesarkan, mendewasakan dan didalamnya anak mendapatkan pendidikan yang pertama kali. Oleh karena itu keluarga merupakan suatu peranan penting dalam perkembangan anak, keluarga yang baik akan berpengaruh positif bagi perkembangan anak Saat ini banyak keluarga yang mengalami konflik yang mana konflik tersebut mengakibatkan adanya perceraian. Adanya perceraian tersebut berdampak buruk bagi anak, hal ini terbukti dampak dari perceraian tersebut menjadikan kurangnya interaksi dengan anak. Orang tua yang sudah bercerai mengakibatkan kurangnya interaksi yang terjalin dengan anak. Hal ini berbeda ketika mereka sama-sama masih dalam sebuah keluarga (Wardhani, 2016).

\section{Perceraian}

Perceraian dapat diartikan sebagai berakhirnya suatu hubungan suami dan istri yang diputuskan oleh hukum atau agama (talak) karena sudah tidak ada saling ketertarikan, saling percaya dan juga sudah tidak ada kecocokan satu sama lain sehingga menyebabkan ketidakharmonisan dalam rumah tangga (Untari, dkk, 2018).

Adapun bentuk-bentuk perceraian, diantaranya yaitu: Pertama, perceraian atas kehendak Allah sendiri melalui matinya salah satu pasangan. Kematian salah seorang suami atau istri menyebabkan berakhirnya hubungan perkawinan. Kedua, perceraian atas kehendak suami karena alasan tertentu dan dinyatakan dengan ucapan tertentu. Perceraian dalam bentuk ini disebut talaq. Ketiga, perceraian atas kehendak istri, karena melihat sesuatu yang menghendaki putusnya perkawinan sedangkan suami tidak berkehendak untuk itu. Keinginan perceraian disampaikan istri dengan cara tertentu, hal ini diterima oleh suami dan dilanjutkan dengan ucapan untuk bercerai. Putusnya perkawinan dengan cara ini disebut khulu'. Keempat, perceraian atas kehendak hakim sebagai pihak ketiga setelah melihat adanya sesuatu pada suami atau istri yang menandakan tidak dapatnya hubungan perkawinan dilanjutkan. Putusnya perkawinan dalam bentuk ini disebut fasakh. Selain itu, dampak perceraian bagi anak diantaranya anak menjadi mudah marah, frustrasi, dan ingin melampiaskannya dengan melakukan hal-hal yang berlawanan dengan ketentuan atau norma sosial, seperti memberontak dan lain sebagainya. Selain itu, bila anak tinggal dengan ibu, anak akan kehilangan figur otoritas ayah. Ketika figur otoritas itu menghilang, anak seringkali tidak begitu takut dengan ibunya. Dampak lain adalah anak menjadi kehilangan jati diri sosialnya atau identitas sosial, mendapatkan 
status sebagai anak cerai memberikan suatu perasaan berbeda dari anak-anak lain (Hafiza, dkk, 2018).

Perceraian dalam keluarga manapun merupakan peralihan besar dan penyesuaian diri baru bagi anak-anak, mereka akan mengalami reaksi emosi dan perilaku karena kehilangan satu orang tua. Bagaimana anak bereaksi terhadap perceraian orangtuanya, sangat dipengaruhi oleh cara orangtua berperilaku sebelum, selama dan sesudah perceraian. Anak akan membutuhkan dukungan, kepekaan, dan kasih sayang yang lebih besar untuk membantunya mengatasi kehilangan yang dialaminya selama masa sulit (Ningrum, 2013).

\section{Pengaruh Perceraian Orangtua Bagi Anak}

Perceraian adalah putusnya ikatan perkawinan sebab dinyatakan talak oleh seorang suami terhadap istri yang perkawinannya dilangsungkan menurut agama islam, yang dapat juga disebut sebagai cerai talak (Rachmadi, 2003). Perceraian merupakan suatu peristiwa yang sangat tidak diinginkan bagi setiap pasangan dan keluarga. Perceraian yang terjadi menimbulkan banyak hal yang tidak mengenakkan dan kepedihan yang dirasakan semua pihak, termasuk kedua pasangan, anak-anak, dan kedua keluarga besar dari pasangan tersebut. terdapat banyak faktor yang mengharuskan pasangan berpisah atau bercerai. salah satu alasan pasangan bercerai adalah masalah komunikasi. Komunikasi yang terhambat disinyalir menjadi penyebab perceraian. pasangan yang terus dapat membina bahtera rumah tangga perlu mendengarkan dan menghargai satu sama lain sekalipun mereka tidak sependapat dalam mengatasi persoalan yang terjadi (Kertamuda, 2019). Komunikasi antara suami dan istri harus saling terbuka, berlangsung dua arah. pada dasarnya tidak ada rahasia antara suami dan istri, sehingga dengan demikian satu sama lain saling terbuka. dengan komunikasi yang terbuka antar anggota keluarga, maka akan terbina saling pengertian, saling mengisi, saling mengerti, dan akan terhindar dari kesalahpahaman (Walgito, 2004).

Pada kasus perceraian, pada umumnya memang anak menyalahkan orang tua terhadap rasa sakit yang timbul akibat perceraian. Namun pada kasus tertentu, anak juga menyalahkan diri sendiri dan bahkan menganggap dirinya sebagai bagian penyebab perceraian. Dalam hal ini, anak tidak hanya perlu melakukan pemaafan pada kedua orang tuanya, namun yang jauh lebih penting adalah memaafkan dirinya sendiri (Hendi, dkk, 2011).

Keluarga adalah lembaga pertama dan utama bagi anak, yaitu tempat bersosialisasi yang memegang peranan penting bagi perkembangan kepribadian anak. Dalam keluarga, pertama kali anak mengenal arti hidup, cinta kasih, simpati, mendapat bimbingan dan pendidikan serta terciptanya suasana yang aman. Hal ini dapat dikatakan, keluarga memegang peranan penting untuk membentuk kepribadian. Akan tetapi, dalam kenyataanya, tidak semua keluarga dapat menjalankan fungsinya dengan baik. Terdapat banyak persoalan yang dihadapi oleh anggota keluarga. Seringkali keseimbangan akan terganggu dan membahayakan kehidupan keluarga yang mengakibatkan keluarga tidak akan merasakan kebahagiaan. Salah satunya adalah masalah perceraian orang tua. Masalah perceraian yang terjadi di tengah keluarga membuat permasalahan baru. Apabila suami istri yang bercerai sudah memiliki anak, maka akan timbul masalah pada anak. Dengan demikian, anak menjadi kehilangan peran pengasuhan sesungguhnya dari orang tua laki-laki maupun perempuan. Apabila anak tidak mendapat pengasuhan yang baik dalam keluarga, maka perkembanganya akan terhambat serta anak akan cenderung berkelakuan kurang baik. Perceraian memberikan berbagai dampak pada perkembangan anak (Widiastuti, 2015).

Keluarga broken home adalah keluarga yang hubungan antar anggotanya 
tidak terjalin dengan baik; antar anggota keluarga tidak saling terhubung, komunikasinya tidak jalan. Kondisi sebagai orangtua dalam keluarga bercerai memang tidak semua bisa menghadapi, apalagi jika ditambah pandangan dan komentar miring sebagian masyarakat. Penghormatan cukup dengan mengahargai orangtua dalam keluarga bercerai sebagai seorang manusia atas segala perjuangan yang dihadapinya dan menerima struktur keluarga yang dianut oleh seorang orangtua dalam keluarga bercerai (meliputi orangtua dan anak) (Rahmawati, 2016).

Keutuhan sebuah keluarga (ayah, ibu, anak) merupakan salah satu faktor dalam menguatkan moral anak, hal ini akan berbeda bila keluarga tidak utuh atau single parent, dalam hal ini bagi orang tua tunggal (ibu) dalam mengembangkan moralitas anak (Nurdiana, dkk, 2017). Single parent adalah orang yang melakukan tugas sebagai orangtua (ayah atau ibu) seorang diri, karena kehilangan/terpisah dengan pasangannya (Wulandari, 2017).

Fenomena marak dan mudahnya pasangan suami istri melakukan perceraian sedikit banyak dipengaruhi oleh tayangan infotainment kawin-cerai para selebritis yang ditayangkan oleh hampir semua media elektronik. Diakui atau tidak tayangantayangan media elektronik televisi yang memapar selama 24 jam sehari telah mengakibatkan perubahan nilai di masyarakat. Berbeda dengan dulu, dimana suami-istri (khususnya istri) akan lebih memilih sikap bertahan demi keutuhan keluarganya apapun masalah yang sedang dihadapi. Namun kini terlihat begitu mudahnya sepasang suami-istri lebih memilih bercerai untuk menyelesaikan permasalahan yang terjadi di keluarganya. Perubahan nilai-nilai sosial yang sedang terjadi di tengah masyarakat Indonesia tampaknya membuat tingkat perceraian semakin tinggi (Prianto, dkk, 2013).

\begin{tabular}{llr}
\multicolumn{2}{c}{ Perceraian orang tua banyak } \\
memberikan dampak negatif bagi \\
perkembangan anak dimasa yang akan
\end{tabular}

datang. Berdasarkan beberapa riset, $25 \%$ anak hasil perceraian ketika masa dewasa awal memiliki masalah serius secara sosial, emosional atau psikologis dibandingkan $10 \%$ dari anak yang orang tuanya tetap bersama. Anak dalam keluarga orangtua tunggal melakukan dapat melakukan semua hal dengan baik, tetapi cenderung tidak lancar dalam urusan sosial dan pendidikan dibandingkan anak yang tinggal dengan kedua orangtua. Anak akan melakukan hal yang baik jika bersama dengan orang tua yang hidup bersama dalam pernikahan daripada tanpa pernikahan. Hal ini berarti, Keluarga yang tidak stabil memungkinkan untuk terjadinya perkembangan yang membahayakan. Anak cenderung memiliki masalah perilaku, dan terjebak dalam kenakalan (Suprihatin, 2018).

Dalam mewujudkan keluarga harmonis bukan perkara yang mudah seperti membalikkan telapak tangan. Berbagai perselisihan dan masalah yang timbul antara suami istri dapat memicu pertengkaran yang berujung pada perceraian. Pada akhirnya, tidak dapat terelakkan, anak juga ikut menanggung akibatnya. Pasangan yang bercerai berusaha semaksimal mungkin untuk mengurangi dampak buruk dari perpecahan rumah tangga mereka dengan berbagai cara agar tidak menimbulkan permasalahan-permasalahan serius pada anak-anak mereka. Namun sulit dihindari, perceraian dan perpisahan orang tua menjadi faktor yang sangat berpengaruh bagi pembentukan perilaku dan kepribadian anak nantinya. Ketidakharmonisan keluarga memengaruhi perkembangan kepribadian anak, dan banyak penelitian mengungkapkan banyaknya dampak buruk perceraian bagi anggota keluarga khususnya bagi seorang anak. Proses perceraian, bagi anak merupakan masa dimana sedang mengalami pengalaman transgresi (pengalaman disakiti atau mendapat perlakuan tidak adil dari diri sendiri ataupun orang lain) (Yakin, 2016). 


\section{KESIMPULAN DAN REKOMENDASI}

Dengan demikian, maka penulis dapat menyimpulkan bahwa perceraian memiliki pengaruh terhadap psikologis anak. Anak-anak mengalami kondisi dimana, mereka tidak menerima keberadaan ayahnya jika sang ayah membawa perempuan lain yang bukan ibunya sendiri. Dengan demikian, anak mengalami ketidaknyamanan di dalam berkomunikasi dengan ayahnya. Sehingganya, sang Ibu dari anak-anak tersebut, harus bisa mengatur waktu dalam berkomunikasi dengan ayahnya agar anak-anak tidak kekurangan kasih sayang dari kedua orangtuanya meskipun sudah bercerai. Perceraian memberikan dampak pada perkembangan anak. Perceraian berpengaruh pada psikologis anak yang membuat mereka kehilangan cinta dari kedua orang tuanya sehingga membuat salahsatu sebab aspek perkembangan anak akan terhambat. Orangtua yang bercerai, akan berpengaruh pada psikologis anak diantaranya yaitu anak kurang mendapat perhatian, perlindungan dari rasa aman, cinta kasih sayang dari ayah dan ibunya.

\section{DAFTAR KEPUSTAKAAN}

Aziz, Muklhis. 2019. Perilaku Sosial Anak Remaja Korban Broken Home Dalam Berbagai Perspektif. Jurnal Al-Ijtimaiyyah: Media Kajian Pengembangan Masyarakat. Vo. 1. No. 1.

Bimo Walgito. 2004. Bimbingan dan Konseling Perkawinan. Yogyakarta: Andi.

Cahyani, Kurnia Dwi. 2016. Masalah dan Kebutuhan Orang Tua Tunggal Sebagai Kepala Keluarga. EJournal Bimbingan dan Konseling. Vol 5. Ed. 8.

Fatchiah E Kertamuda. 2009. Konseling Pernikahan Untuk Keluarga
Indonesia. Jakarta: Salemba Humanika.

Hafiza, Sarah, and Marty Mawarpury 2018. Pemaknaan Kebahagiaan oleh Remaja Broken Home. Psympathic: Jurnal Ilmiah Psikologi. Vol 5. No. 1.

Haryanie, Sri Widha, Retty Filiani, Wirda Hanim. 2013. Dampak Perceraian Orang Tua Terhadap Emosi Anak. Insight: Jurnal Bimbingan dan Konseling. Vol. 2 No. 1.

Hasanah, Uswatun. 2018. Metode Pengembangan Moral dan Disiplin Bagi Anak Usia Dini. Martabat: Jurnal Pendidikan dan Anak. Vol. 2 No. 1.

Hasanah, Uswatun. 2017. Pola Asuh Orangtua Dalam Membentuk Karakter Anak. Elementary: Jurnal Ilmiah Pendidikan Dasar . Vol 2. No. 2.

Hendi, Suhendi, \& Ramdani Wahyu. 2001. Pengantar Studi Sosiologi Keluarga. Bandung: Pustaka Setia.

Isma, Nur. 2016. Peranan Orang Tua Tunggal (Single Parent) Dalam Pendidikan Moral Anak (Studi Kasus Delapan Orang Ayah Di Desa Songing Kecamatan Sinjai Selatan Kabupaten Sinjai). Jurnal Sosialisasi. Vol. 3, No. 1.

Jannah, Daratul. 2018. Single Parent: Ayah Sebagai Pembina Moral Anak. Ranah Research: Journal of Multidisciplinary Research and Development. Vol 1. No. 1.

Mokalu, Priscilia V, Stefi H Harilama, \& Norma Mewengkang. 2015. Konstruksi Diri Anak Pasca Perceraian Orangtua Di Lingkungan Masyarakat Kelurahan Karombasan Utara 
Kecamatan Wanea Kota Manado. Acta Diurna Komunikasi. Vol. 4. No. 5.

Nim, Oetari Wahyu Wardhani. 2016. Problematika Interaksi Anak Keluarga Broken Home. Vol. 2. No. 2.

Ningrum, Putri Rosalia. 2013. Perceraian Orang Tua Dan Penyesuaian Diri Remaja. Psikoborneo: Jurnal Ilmiah Psikologi. Vol. 1. No. 1.

Nurdiana, Nurdiana, Maman Rachman, \& Suwito Eko Pramono. 2017. Peran Orang Tua Tunggal (Ibu) Dalam Mengembangkan Moralitas Anak Di Kelurahan Tlogo Mulyo Kecamatan Pedurungan Semarang. Journal of Educational Social Studies. Vol 6. No. 1.

Prianto, Budhy, Nawang Warsi Wulandari, \& Agustin Rahmawati. 2013. Rendahnya Komitmen Dalam Perkawinan Sebagai Sebab Perceraian. Komunitas: International Journal of Indonesian Society and Culture. Vol. 5. No. 2.

Rahmawati, Febby. 2016. Pola Asuh Keluarga Bercerai Dalam Membentuk Perilaku Anak. Journal Universitas Airlangga. Vol. 5. No. 2.

Suprihatin, Titin. 2018. Dampak Pola Asuh Orang Tua Tunggal (Single Parent Parenting) Terhadap
Perkembangan Remaja. Prosiding Seminar Nasional Psikologi Unissula: penguatan keluarga di zaman now: Fakultas Psikologi Lt.3, 12 Mei 2018.

Untari, Ida, Kanissa Puspa Dhini Putri, \& Muhammad Hafiduddin. 2018. Dampak Perceraian Orang Tua Terhadap Kesehatan Psikologis Remaja. Profesi (Profesional Islam): Media Publikasi Penelitian. Vol. 15. No. 2.

Usman Rachmadi. 2003. Pilihan Penyelesaian Sengketa Di Luar Pengadilan. 2003rd ed. Bandung: Citra Aditya Bakti.

Widiastuti, Reski Yulina. 2015. Dampak Perceraian Pada Perkembangan Sosial Dan Emosional Anak Usia 5-6 Tahun. Jurnal PG-PAUD Trunojoyo: Jurnal Pendidikan Dan Pembelajaran Anak Usia Dini. Vol. 2. No. 2.

Wulandari, Agathista Eka. 2017. Parenting Pada Single Parent (Ibu) Yang Memiliki Anak Autis. Jurnal PGPAUD Trunojoyo: Jurnal Pendidikan dan Pengajaran Anak Usia Dini. Vol. 4. No. 1.

Yakin, Ahmad Al. 2016. Dampak Perceraian Orang Tua Terhadap Anak (Studi Kasus Di Sma Negeri 1 Kecamatan Nosu Kabupaten Mamasa. Pepatudzu: Media Pendidikan dan Sosial Kemasyarakatan. Vol. 8. No.1 